\title{
KESALAHAN IMPLEMENTASI TEKNIK TRIANGULASI PADA UJI VALIDITAS DATA SKRIPSI MAHASISWA JURUSAN PENDIDIKAN SENI RUPA FBS UNY
}

\author{
Kasiyan \\ Jurusan Pendidikan Seni Rupa \\ Fakultas Bahasa dan Seni \\ Universitas Negeri Yogyakarta \\ Email: kasiyan01@gmail.com
}

\begin{abstract}
Abstrak
Tujuan penelitian ini adalah untuk mengidentifikasi, mendeskripsi, dan mengeksplanasi: 1) Pelbagi bentuk kesalahan implementasi teknik triangulasi pada uji validitas data skripsi mahasiswa Jurusan Pendidikan Seni Rupa FBS UNY dan 2) Faktor penyebab terjadinya kesalahan implementasi teknik triangulasi sebagaimana dimaksud.

Metode penelitian ini adalah kualitatif dengan perspektif kritis weltanschauung yang bertujuan sebagai kritik atas realitas kekurangan tentang sesuatu hal, untuk kemudian dikonstruksi konsep baru, yakni terkait dengan implementasi teknik triangulasi dalam penelitian seni. Penelitian ini juga termasuk dalam penelitian kepustakaan (library research) dengan pendekatan hermeneutik, karena sumber datanya berupa dokumentasi skripsi mahasiswa. Instrumen utama penelitian ini adalah peneliti sendiri sebagai human instrument, yang dibantu dengan pedoman dokumentasi. Spasial waktu sumber data dalam penelitian ini menggunakan data skripsi dalam rentang lima tahun terakhir (2008-2013), dengan harapan mampu menghadirkan informasi data yang komprehensif.Teknik pengumpulan data dalam penelitian ini ditempuh dengan purposive sampling (jugdmental sampling). Sementara itu, analisis datanya menggunakan teknik analisis deskritif kualitatif.

Hasil penelitian ini dapat dideskripsikan sebagai berikut. Pertama, ditemukan tiga pola kategori kesalahan implementasi teknik triangulasi pada skripsi mahasiswa yang berbasis: a) penghadiran pendapat ahli/pakar (expert judgment); b) ketidakmampuan membedakan jenis teknik triangulasi yang digunakan; dan c) ketidakjelasan konsep triangulasi yang digunakan. Kedua, faktor penyebab terjadinya kesalahan implementasi triangulasi tersebut, adalah bersifat internal (diri mahasiswa) dan eksternal (dosen), yang mempunyai kekurangan wawasan dan pengetahuan tentang metodologi triangulasi dalam penelitian.
\end{abstract}

Kata-kata Kunci: kesalahan, implementasi, teknik triangulasi, uji validitas data, skripsi mahasiswa.

Errors in the Implementation of Triangulation Technique in Testing the Data Validity Found in Students' Theses at Fine Arts Education Department of FBS UNY

\footnotetext{
Abstract

This study was aimed to identify, describe, and explain: 1) various forms of errors in the implementation of triangulation technique in testing the data validity found in the students' theses at Fine Arts Education Department, FBS UNY; and 2) factors causing those errors.

The qualitative research method of weltanschauung critical perspective was used in this study. This study is a kind of library research that was conducted using hermeneutic perspective to discuss the source of the data, that is the students' theses. The main instrument
} 
applied in this study was the researcher himself with the help of documentation guide. The time space of the study was the last five years (2008-2013). The purposive sampling (judgmental sampling) was used in collecting the data. Meanwhile, to analyze the data, the descriptive qualitative analysis technique was used.

The results of the study showed the following. Firstly, there were three categories of errors in the implementation of triangulation technique found in the students' thesis which were merely based on: $a$. the use of expert judgment; b. the students' lack of knowledge in differentiating types of triangulation techniques; $c$. their unclear concept of triangulation technique. Secondly, factors causing those errors can be categorized as internal factors (coming from the students) and the external ones (coming from the lecturers). Both students and lecturers may have lack of knowledge of the right triangulation method in research.

Keywords: errors, implementation, triangulation technique, test of data validity, students' thesis.

\section{A. PENDAHULUAN}

Salah satu tuntutan yang senantiasa diamanatkan pada mahasiswa sebagai bagian dari kalangan cendekiawan adalah kemampuannya untuk mengembangkan ilmu pengetahuan dan kebudayaan melalui salah satu sarananya yang amat khas, yakni aktivitas penelitian. Penelitian adalah rangkaian pengamatan yang sambung menyambung, berakumulasi, dan melahirkan teori-teori yang mampu menjelaskan dan meramalkan fenomena-fenomena (Rakhmat, 2007). Penelitian sering diasosiasikan dengan metode ilmiah, sebagai tata cara sistematis yang digunakan untuk melakukan penelitian.

Salah satu penerapan penelitian atau metode ilmiah di kalangan mahasiswa adalah dalam bentuk penulisan skripsi, yang lazimnya ditempatkan sebagai tugas akhir mahasiswa selama kuliah di perguruan tinggi untuk jenjang sarjana strata satu (S1). Demikian juga halnya dengan konteks spesifik mahasiswa di Jurusan Pendidikan Seni Rupa, FBS, UNY, pembuatan skripsi juga ditempatkan sebagai pilihan untuk tugas akhir, di samping pilihan lain yakni berupa pembuatan dan pameran karya seni.

Dalam konteks spesifik, tugas akhir penulisan skripsi yang dikerjakan oleh mahasiswa di Jurusan Pendidikan Seni Rupa, FBS, UNY, jenis perspektif metodologi yang digunakan cenderung berbentuk kualitatif, meskipun kenyataan tersebut bukan sebagai arus utama dalam penelitian seni dan budaya di masyarakat dan kalangan akademik pada umumnya. Hal ini berangkat dari pertimbangan bahwa keilmuan seni merupakan bagian dari keilmuan sosial budaya dan humaniora yang memiliki karakteristik yang relatif khas jika dibandingkan dengan keilmuan alam atau sains. Sains menjelaskan fakta-fakta, yang benar-benar nyata dan ada, dapat dibuktikan, cenderung permanen, umum, dan terkait dengan pengalaman-pengalaman universal. Ilmu pengetahuan alam membatasi dirinya dengan hanya membahas gejala-gejala alam yang dapat diamati. Sementara itu ilmu sosial, terutama seni, lebih mengambang, individual, relatif, terkait erat dengan nilai-nilai dan rasa (sense), serta membatasi diri pada gejala kehidupan manusia, baik itu gejala yang bersifat fisik maupun bukan (Lubis, 2010:100).

Namun demikian, akibat hegemoni ilmu alam, dapat dikatakan bahwa sampai saat ini keilmuan sosial termasuk seni dan budaya banyak yang menggunakan perspektif metodologi 
kuantitatif daripada kualitatif. Fenomena ini sebenarnya tidak lepas dari peran kaum positivisme yang sangat dominan pada Abad ke-20, yang mengajukan doktrin kesatuan ilmu. Doktrin inilah yang mendasari bahwa keabsahan suatu ilmu harus didasarkan pada kesatuan metode dan bahasa. Menurut kaum positivis, ilmu sosial secara epistimologis, metodologis, dan ontologis wajib mengikuti ilmu alam (Lubis, 2010:100).

Oleh karena itu, praktik penelitian seni yang banyak menggunakan metode dan perspektif kualitatif dalam konteks skripsi mahasiswa Jurusan Pendidikan Seni Rupa, FBS, UNY merupakan satu langkah positif yang layak mendapatkan empati apresiatif. Namun, yang menjadi persoalan adalah, pemahaman berikut penerapan metode dan perspektif kualitatif untuk penelitian seni tersebut, dari hasil pengamatan di lapangan sering masih menunjukkan adanya pelbagai kekurangan atau bahkan kesalahan. Salah satu kekurangan atau bahkan kesalahan sebagaimana dimaksud adalah dalam hal implementasi teknik triangulasi untuk kepentingan uji validitas atau kesahihan data. Sebagaimana dalam penelitian kuantitatif, penelitian kualitatif juga mengenal uji validitas, meski secara prinsip mempunyai perbedaan mendasar. Dalam penelitian kuantitatif untuk mendapatkan data yang valid dan reliabel yang diuji validitas dan reliabilitasnya adalah instrumen penelitiannnya. Sementara itu, dalam penelitian kualitatif yang diuji adalah datanya.

Adapun salah satu teknik untuk uji validitas data dalam penelitian kualitatif yang dilakukan oleh mahasiswa Jurusan Pendidikan Seni Rupa, FBS, UNY untuk penulisan skripsi adalah teknik triangulasi. Triangulasi pada hakikatnya merupakan pendekatan multimetode yang dilakukan peneliti pada saat melakukan penelitian, mengumpulkan, dan menganalisis data. Ide dasarnya adalah bahwa fenomena yang diteliti dapat dipahami dengan baik, sehingga diperoleh kebenaran tingkat tinggi jika didekati dari berbagai sudut pandang. Berbagai sudut pandang dalam teknik triangulasi itu, paling tidak terkait dengan empat hal, yakni (1) sumber, (2) peneliti, (3) metode, dan (4) teori.

Namun dalam praksinya, penerapan teknik triangulasi yang dilakukan oleh mahasiswa Jurusan Pendidikan Seni Rupa, FBS, UNY dalam karya skripsinya cenderung salah. Kesalahan-kesalahan tersebut terkait dengan kekeliruan dalam penerapan teriangulasi sumber, yang dalam banyak kesempatan, mahasiswa banyak menggunakan konsep atau terminologi expert judgment atau ahli/pakar. Fakta di lapangan menunjukkan bahwa hampir setiap teknik triangulasi yang dilakukan oleh mahasiswa Jurusan Pendidikan Seni Rupa, FBS, UNY dalam skripsinya direduksi dengan menggunakan konsep expert judgment ini. Padahal, konsep expert judgment dalam penelitian lebih digunakan dalam konteks penelitian eksperimen atau studi pengembangan (R\&D). Fenomena ini tentunya merupakan bentuk kesalahan yang cukup mendasar dari kerja penelitian.

Berdasarkan latar belakang tersebut maka penelitian tentang "Kesalahan Implementasi Teknik Triangulasi padaUji Validitas Data Skripsi Mahasiswa Jurusan Pendidikan Seni Rupa FBS UNY” ini penting untuk dilakukan. Fokus masalah penelitian ini ada dua, yakni untuk mengkaji: 1) pelbagai bentuk kesalahan implementasi teknik triangulasi untukuji validitas data skripsi mahasiswa Jurusan Pendidikan Seni Rupa, FBS, UNY; dan 2) Faktor yang menyebabkan terjadinya kesalahan implementasi teknik triangulasi sebagaimana dimaksud. 


\section{A. KAJIAN TEORI}

\section{Tinjauan tentang Konsep Skripsi dan Penelitian}

Skripsi adalah istilah yang digunakan di Indonesia untuk mengilustrasikan suatu karya tulis ilmiah berupa paparan tulisan hasil penelitian sarjana S1 yang membahas suatu permasalahan dalam bidang ilmu tertentu dengan menggunakan kaidah-kaidah yang berlaku. Skripsi bertujuan agar mahasiswa mampu menyusun dan menulis suatu karya ilmiah, sesuai dengan bidang ilmunya. Mahasiswa yang mampu menulis skripsi dianggap mampu memadukan pengetahuan dan keterampilannya dalam memahami, menganalisis, menggambarkan, dan menjelaskan masalah yang berhubungan dengan bidang keilmuan yang diambilnya. Skripsi merupakan persyaratan untuk mendapatkan status sarjana (S1) di setiap perguruan tinggi yang ada di Indonesia.

Adapun fungsi tugas akhir skripsi adalah untuk memberikan pengalaman kepada mahasiswa tentang penelitian ilmiah sesuai dengan spesialisasinya (Panduan Tugas Akhir, FBS, UNY, 2011:1). Pengalaman penelitian sangat penting bagi mahasiswa, karena mereka adalah bagian dari elite cendekiawan yang diharapkan menjadi agen bagi pengembangan ilmu pengetahuan dan juga kebudayaan di masa mendatang. Hal ini sejalan dengan makna penelitian sebagai aktivitas mempelajari secara hati-hati (careful study) atau menyelidiki (investigation), khususnya untuk menemukan (to discover) fakta-fakta atau informasi ilmiah baru. Penelitian dilakukan terhadap suatu masalah secara bersistem, kritis, dan ilmiah. Tujuannya ialah untuk meningkatkan pengetahuan dan pengertian, mendapatkan fakta baru, atau melakukan penafsiran lebih baik, dan membentuk ilmu baru. Ilmu dibentuk oleh tiga komponen yang saling terkait, antara aktivitas manusia, metode tertentu, dan sistem (Gie, 2000: 88).

\section{Metodologi Kualitatif dalam Penelitian untuk Keilmuan Seni}

Penelitian dalam bidang ilmu-ilmu sosial budaya, termasuk seni, selama ini terlalu menekankan pada pendekatan penelitian kuantitatif. Penelitian kuantitatif yang dilandasi faham positivisme empirik dan berintikan aktivitas penelitian eksperimental memang telah memiliki pengaruh yang sangat kuat dalam berbagai bidang ilmu, bahkan pernah dipandang sebagai satusatunya pendekatan penelitian yang benar dan ilmiah. Pandangan tersebut mampu menyeret para peneliti ilmu-ilmu sosial budaya yang, dalam perkembangan aktivitasnya, semakin sering menghadapi beragam permasalahan yang tidak dapat dijawab secara tuntas. Dari kenyataan yang dihadapi tersebut, para peneliti semakin manyadari bahwa manusia sebagai subjek, dengan segala sifatnya yang subjektif, tidak mungkin dapat dikaji secara tepat dengan pendekatan ilmu objektif. Pemaksaan ke arah itu akan menimbulkan bias fundamental dan mengakibatkan kekeliruan fatal yang menjadi sumber krisis ilmu-ilmu sosial di masa kini. Masalah sosial yang kompleks tak mungkin untuk diuji dengan pandangan partial dan linear. Di dalam ilmu alam berbagai masalah pokok didasarkan pada kenyataan objek yang dapat dilihat di luar diri manusia dan bebas sebagai fakta objektif. Kenyataan itu sangat berbeda halnya dengan ilmu sosial budaya, termasuk seni, yang memusatkan studinya pada realitas sebagai produk pikir manusia dengan segala subjektivitas emosi serta nilai-nilai yang dianutnya. Fenomena sosial dan perilaku manusia pada dasarnya hanya ada dalam pikiran manusia. Realitas tersebut terikat oleh interaksi dialektis antara subjek dan objek. 
Dari kenyataan tersebut, paradigma dan metode penelitian menjadi persoalan paling sering muncul di hadapan peneliti seni (Martopo, 2007) Seni hakikatnya memang berbeda dari sains, seperti dikatakan Melvin Rader (1960: xx), "Science describes facts; art expresses values". Sains menjelaskan fakta-fakta, yang benar-benar nyata dan ada, dapat dibuktikan, sesuatu yang permanen, umum, dan terkait dengan pengalaman-pengalaman universal. Sains memang terkait dengan sesuatu yang pasti dan masuk akal (logic); sedangkan seni lebih mengambang, individual, relatif, dan terkait erat dengan nilai-nilai dan rasa (sense). Otonomi seni lebih dari sekadar menggambarkan fakta atau realitas belaka, tetapi menyampaikan pesan-pesan artistik.

Oleh karena itu, metodologi penelitian seni perlu dibangun dengan memperhatikan hakikat seni yang khusus, terutama disebabkan seni adalah aktivitas yang berkelindankan proses cipta, rasa, dan karsa, yang relatif berbeda dari sains dan teknologi. Aspek 'cipta' dalam seni mengandung pengertian terpadu antara kreativitas, penemuan, dan inovasi yang kesemuanya sangat dipengaruhi oleh kepekaan rasa atau emotion, feeling (Bandem, 2005). Metodologi penelitian kualitatif kiranya relatif lebih tepat untuk mengerangkai pelbagai kekhasan dalam dunis seni itu.

\section{Triangluasi sebagai salah satu Tekni Uji validitas Data dalam Penelitiuan Kualitatif}

Salah satu hal penting yang merupakan bagian dari proses penelitian, baik yang sifatnya kualitatif maupun kualitatif, adalah uji validitas atau kesahihan data. Validitas merupakan derajat ketepatan antara data yang terjadi pada objek penelitian dengan yang dilaporkan oleh peneliti. Dengan demikian, data yang valid adalah data “yang tidak berbeda” antara data yang dilaporkan oleh peneliti dengan data yang sesungguhnya terjadi pada objek penelitian.

Ada perbedaan yang mendasar mengenai validitas dalam penelitian kuantitatif dan penelitian kualitatif. Dalam penelitian kuantitatif untuk mendapatkan data yang valid dan reliabel yang diuji validitas dan reliabilitasnya adalah instrumen penelitiannnya. Sementara itu, dalam penelitian kualitatif yang diuji adalah datanya. Dalam penelitian kualitatif, temuan atau data dapat dinyatakan valid apabila tidak ada perbedaan antara yang dilaporkan peneliti dengan apa yang sesungguhnya terjadi pada objek yang diteliti.

Adapun salah satu cara untuk uji validitas data dalam penelitian kualitatif yang cukup populer adalah teknik triangulasi. Triangulasi pada hakikatnya merupakan pendekatan multimetode yang dilakukan peneliti pada saat melakukan penelitian, mengumpulkan, dan menganalisis data. Ide dasarnya adalah bahwa fenomena yang diteliti dapat dipahami dengan baik sehingga diperoleh kebenaran tingkat tinggi jika didekati dari berbagai sudut pandang. Memotret fenomena tunggal dari sudut pandang yang berbeda-beda akan memungkinkan diperoleh tingkat kebenaran yang handal.

Dalam kaitannya dengan hal ini, Sutopo (2006) menyatakan bahwa terdapat empat macam teknik triangulasi, yaitu (1) triangulasi data/sumber (data triangulation), (2) triangulasi peneliti (investigator triangulation), (3) triangulasi metodologis (methodological triangulation), dan (4) triangulasi teoretis (theoritical triangulation). Pada dasarnya triangulasi ini merupakan teknik yang didasari pola pikir fenomenologi yang bersifat multiperspektif. Artinya, untuk menarik kesimpulan yang mantap, diperlukan tidak hanya dari satu sudut pandang saja. 
Menurut Moleong (2005: 330-331) teknik triangulasi dengan sumber berarti membandingkan dan mengecek balik derajat kepercayaan suatu informasi yang diperoleh melalui waktu dan alat yang berbeda. Hal tersebut dapat dilakukan melalui: a) perbandingan data hasil pengamatan dengan hasil wawancara; b) perbandingan apa yang dikatakan seseorang di depan umum dengan apa yang diucapkan secara pribadi; c) perbandingan apa yang dikatakan tentang situasi penelitian dengan apa yang dikatakan sepanjang waktu; d) perbandingan keadaan dan perspektif seseorang berpendapat sebagai rakyat biasa, dengan yang berpendidikan dan pejabat pemerintah; dan e) membandingkan hasil wawancara dengan isi suatu dokumen yang berkaitan. Hasil dari perbandingan yang diharapkan adalah berupa kesamaan atau alasan-alasan terjadinya perbedaan.

Kedua, tentang teknik triangulasi penyidik, yakni dengan memanfaatkan penelitian atau pengamat lainnya untuk pengecekan kembali derajat kepercayaan data. Cara lain adalah membandingkan hasil pekerjaan seorang analisis dengan yang lainnya, dan pemanfaatan teknik untuk mengurangi pelencengan dalam pengumpulan suatu data hasil penelitian.

Ketiga, triangulasi metode, yakni pengecekan derajat kepercayaan penemuan hasil penelitian melalui beberapa teknik pengumpulan data. Sementara itu, keempat, teknik triangulasi teori, yakni terkait dengan hasil akhir penelitian kualitatif berupa sebuah rumusan informasi atau thesis statement. Informasi tersebut selanjutnya dibandingkan dengan perspektif teori yang televan untuk menghindari bias individual peneliti atas temuan atau kesimpulan yang dihasilkan.

\section{METODE PENELITIAN}

Sejalan dengan karakteristik topik penelitian ini, maka jenis penelitian yang digunakan adalah penelitian kualitatif, yang orientasinya diarahkan untuk kepentingan penggalian data yang sifatnya alamiah dan holistik-kontekstual (Moleong, 2005:3). Data utama yang dimaksud dalam konteks penelitian ini adalah teks skripsi yang dibuat oleh mahasiswa Jurusan Pendidikan Seni Rupa, Fakultas Bahasa dan Seni, Universitas Negeri Yogyakarta, khususnya terkait dengan implementasi 'teknik triangulasi' sebagai salah satu metode atau teknik uji validitas atau pemeriksaan keabsahan data dalam penelitian kualitatif. Secara khusus, penelitian kualitatif yang digunakan dalam penelitian ini dipilih model kualitatif dengan perspektif kritis weltanschauung yang di dalamnya terkandung maksud sebagai bagian dari metode kritik atas realitas kekurangan atau bahkan kekeliruan sesuatu hal, untuk kemudian dapat digagas atau dikonstruksi suatu konsep ‘kebenaran’ yang baru (Muhadjir, 2000:79; Alasuutari, 1996:2). Adapun persoalan kritik yang dikedepankan sebagaimana dimaksud dalam penelitian ini, adalah terkait dengan kemungkinan terdapat kesalahan implementasi, yang sangat mungkin juga disebabkan oleh kesalahan pemahaman tentang teknik triangulasi yang terepresentasi dalam karya skripsi mahasiswa di Jurusan Pendidikan Seni Rupa, FBS, UNY.

Data dalam penelitian ini hanya didasarkan pada karya skripsi yang bermetodologikan kualitatif atau naturalistik. Hal ini dilakukan dengan pertimbangan bahwa teknik triangulasi memang hanya ada dalam ketegori jenis riset atau penelitian yang berparadigmakan kualitatif atau naturalistik. Data yang digunakan menggunakan rentang waktu lima tahun terakhir (2008-2013). Periode waktu tersebut, diharapkan mampu menghadirkan informasi data yang cukup komprehensif. 
Teknik pengumpulan data dalam penelitian ini ditempuh dengan purposive sampling (jugdmental sampling) yang dalam proses kinerjanya peneliti melakukan analisis terhadap karakteristik data tertentu, yang lazimnya adalah terkait dengan ciri atau kategori tertentu dan juga di lokasi atau tempat tertentu. (Johnson, 1995:313; Engel\& Schutt, 2010: 96). Adapun ciri dari prosedur purposive sampling adalah pengumpulan datanya menggunakan teknik sampel bola salju (snowball samping) (Moleong, 2005: 224-225). Instrumen utama dalam penelitian ini adalah peneliti sendiri sebagai human instrument, dibantu dengan pedoman dokumentasi.Untuk teknik analisis data dalam penelitian ini menggunakan teknik analisis deskritif, khususnya lagi model yang dikembangkan Miles dan Huberman (1992:15-21).

\section{HASIL PENELITIAN DAN PEMBAHASAN}

Berdasarkan data-data yang ditemukan di lapangan, maka hasil penelitian ini dapat disampaikan sebagai berikut.

\section{Pelbagi Bentuk Kesalahan Implementasi Teknik Triangulasi padaUji Validitas Data Skripsi Mahasiswa Jurusan Pendidikan Seni Rupa FBS UNY \\ Terkait dengan persoalan pertama, ditemukan tiga pola kategori kesalahan implementasi atau} penerapan teknik triangulasi untuk kepentingan uji validitas atau kesahihah data penelitian. Ketiga pola ketegorisasi tersebut adalah: 1) kesalahan pemahaman dan implementasi konsep triangulasi berbasis penghadiran seorang ahli/pakar (expert judgment); 2) kesalahan pemahaman dan implementasi konsep teknik triangulasi yang berbasis ketidakmampuan membedakan jenis triangulasi yang digunakan; dan 3) kesalahan pemahaman dan implementasi konsep triangulasi yang berbasis ketidakjelasan konsep teknik triangulasi yang digunakan. Deskripsi dari masing-masing persoalan tersebut adalah sebagai berikut.

\section{a. Kesalahan Pemahaman dan Implementasi Konsep Triangulasi Berbasis Penghadiran Seorang Ahli/Pakar (Expert Judgment)}

Hasil penelitian kategori pertama, yakni berupa kesalahan pemahaman berikut penerapan konsep triangulasi dengan penghadiran pendapat ahli/pakar (expert judgment) ini adalah termasuk dalam kategori kesalahan yang paling sering terjadi. Dalam konteks ini, peneliti sering menghadirkan seorang atau beberapa orang yang dianggap ahli di bidang tertentu yang sesuai dengan topik kajian penelitian, dan kemudian orang yang bersangkutan dimintai pendapatnya terkait dengan tindak atau hasil penelitian yang dilakukan oleh peneliti.

Berdasarkan data-data temuan hasil penelitian, dapat disampaikan dua hal penting terkait dengan jenis teknik triangulasi sumber. Pertama, perlu kiranya ditegaskan ulang tentang makna yang benar terkait dengan jenis teknik triangulasi sumber di tingkat konseptual atau terminologinya. Triangulasi sumber adalah salah satu teknik untuk menguji kredibilitas atau validitas data, yang dilakukan dengan cara mengecek data yang telah diperoleh melalui beberapa sumber informan yang relevan dengan konteks subjek penelitian. Sebagai contoh, untuk menguji kredibilitas data tentang gaya kepemimpinan seseorang maka pengumpulan dan pengujian data yang telah diperoleh dilakukan 
ke bawahan yang dipimpin, atasan yang menugasi, dan teman kerja yang merupakan kelompok kerjasama. Data dari beberapa sumber tersebut, tidak bisa dirata-ratakan seperti dalam penelitian kuantitatif, tetapi dideskripsikan, dikategorisasikan, mana pandangan yang sama, mana pandangan yang berbeda, dan mana spesifik dari tiga sumber data tersebut. Data yang telah dianalisis oleh peneliti menghasilkan kesimpulan yang selanjutnya dimintakan kesepakatan dengan tiga sumber data tersebut.

Demikian juga halnya jika konsep tersebut dikenakan pada penelitian karya seni, maka terkait dengan segala hal informasi yang berhubungan dengan karya dan si pembuat karya tersebut, uji validitasnya dilakukan dengan triangulasi sumber. Seharusnya uji ini dilakukan dengan mengadakan wawancara dengan sumber yang relavan dan berhubungan dekat dengan sumber utama (seniman) untuk melihat sejauh mana kebenaran informasi yang disampaikan oleh sang seniman tersebut didukung oleh pihak-pihak terkait yang memang mengetahui keberadaan sang seniman tersebut. Dalam konteks pihak lain sebagai sumber tersebut, sama sekali tidak dipersyaratkan sebagai seorang ahli/pakar (expert judgmnet). Oleh karena itu, penghadiran expert judgment dalam konteks penelitian seperti kasus-kasus di atas merupakan tindakan yang sama sekali tidak dibenarkan secara keilmuan, kecuali memang jenis penelitian itu adalah yang termasuk dalam kategori penelitian pengembangan (research and development/R\&D) (U.S. Congress, Office of Technology Assesment, 1985:102).

\section{b. Kesalahan Pemahaman dan Penerapan Konsep Triangulasi Berbasis Ketidakmampuan Membedakan Jenis Triangulasi yang Digunakan}

Persoalan kedua, yakni kesalahan pemahaman dan implementasi konsep triangulasi yang berbasis ketidakmampuan membedakan jenis triangulasi yang digunakan, terutama terkait dengan adanya kesalahpahaman pemaknaan dan penerapan triangulasi, sesuai dengan kategori jenisnya. Sebagaimana diketahui bahwa teknik triangulasi itu ada empat jenis, yakni triangulasi: 1) sumber; 2) metode; 3) penyidik/peneliti; dan 4) teori. Keempat teknik triangulasi tersebut mempunyai terminologi dan konsep sendiri-sendiri dan berbeda, termasuk juga berbeda implikasi penerapannya. Namun hasil dari penelitian terhadap skripsi mahasiswa Jurusan Pendidikan Seni Rupa FBS UNY, ada persoalan terkait dengan pemahaman dan juga penerapan di antara keempat jenis teknik triangulasi tersebut. Sebagai contoh, ada skripsi yang diklaim uji validitasnya dengan menggunakan jenis triangulasi sumber, tetapi setelah diperiksa lebih lanjut, yang digunakan bukan triangulasi sumber melainkan yang lain.

Triangulasi sumber mestinya dimaknai sebagai kegiatan kross cek data dengan melibatkan pelbagai pihak di luar sumber data utama. Pihak-pihak tersebut diyakini mempunyai relevansi dan hubungan yang dekat dengan subjek penelitian utama. Akan tetapi kenyataannya, skripsi-skripsi yang menjadi sampel sasaran penelitian ini banyak yang menerjemahkan pemahaman triangulasi sumber dengan mencampuradukkan pemahaman dengan teknik triangulasi jenis lainnya, misalnya metode.

\section{c. Kesalahan Pemahaman dan Implementasi Konsep Triangulasi yang Berbasis Ketidakjelasan Konsep Triangulasi yang Digunakan}

Pada kategori ini peneliti, dalam metode penelitiannya, mengklaim menggunakan teknik 
triangulasi, tetapi tidak terdapat kejelasan triangulasi yang digunakan. Dalam kasus ini, kecenderungannya, peneliti hanya menyebutkan menggunakan teknik triangulasi dan memberikan definisi triangulasi tersebut secara umum, sehingga tidak ada kejelasan metodologis dapat dipertanggungjawabkan.

\section{Faktor Penyebab Terjadinya Kesalahan Implementasi Triangulasi}

Sebagaimana halnya dalam sudut pandang sosiologis maupun antropologis pada umumnya, pelbagai fakta, proses, berikut dinamika sosial budaya senantiasa melibatkan pelbagai komponen atau faktor yang amat kompleks. Kompleksitas faktor tersebut jika disederhanakan dapat dikategorisasikan menjadi dua, yakni faktor yang sifatnya internal dan eksternal (Mendelsohn\& Elkana, 1981:47; Halliday\& Janowitz, 1992:44). Faktor internal terkait dengan diri masing-masing pelaku kebudayaan tersebut, sementara faktor eksternal terkait dengan pelbagai kondisi lingkungan yang berada di luar diri si pelaku kebudayaan tersebut. Hubungan dan kondisi interelasional di antara kedua faktor itulah pelbagai fenomena fakta, proses, dan juga perubahan sosial kebudayaan sering dapat ditemukan pemaknaannya yang relevan dan signifikan.

Faktor secara internal terkait dengan keberadaan mahasiswa sebagai pelaku yang melakukan kegiatan penelitian berupa skripsi. Dalam konteks ini, peneliti dengan segala keterbatasan yang ada, mengalami kesulitan untuk menjangkau data-data penelitian yang digali dari mahasiswa selaku pembuat skripsi secara langsung karena sudah lulus dan berada di luar kampus yang sangat sulit untuk dijangkau.

Oleh karena itu, tafsir hermeneutis yang bisa dikembangkan dengan segala keterbatasan atas kenyataan kasus kesalahan implementasi teknik triangulasi dalam karya skripsi yang dibuat tersebut, kemungkinan lebih disebabkan faktor keterbatasan pengetahuan yang benar, yang dimiliki oleh mahasiswa, terkait dengan keilmuan metodologi penelitian tersebut. Hal ini juga mengandung multitafsir berikutnya, yakni terkait dengan faktor penyebab adanya keterbatasan pengetahuan yang benar atas metodologi penelitian, khususnya yang terkait dengan uji validitas data dengan tekni teriangulasi. Pada satu sisi, hal tersebut disebabkan oleh ketidakmampuan atau ketidakmauan mahasiswa untuk belajar dengan baik dan benar melalui pelbagai media dan sumber, baik melalui perkuliahan maupun dengan cara membaca referensi yang relevan. Di sisi lain, juga sangat dimungkinkan mahasiswa tidak cukup mendapat bekal informasi dan pengetahuan yang baik dan benar terkait dengan metodologi triangulasi tersebut, yang berasal dari para dosen, baik ketika mengikuti perkuliahan tentang metodologi penelitian maupun secara khusus dalam kaitannya dengan konteks pembimbingan skripsi. Kemungkinan lain adalah kombinasi di antara kedua faktor tersebut.

Faktor eksternal ternyata bersifat tidak tunggal, tetapi plural. Satu hal yang kiranya menduduki posisi dan juga peran yang amat strategis terkait dengan hal ini, di antaranya adalah keberadaan dosen, baik dalam konteks pengampu mata kuliah metodologi penelitian seni yang memberikan bekal pemahaman yang benar kepada mahasiswa, maupun secara khusus sebagai pembimbing penulisan skripsi, yang membantu memberikan pelbagai saran dan arahan ketika mahasiswa mengerjakan proses pembuatan skripsi secara keseluruhan. Artinya, dapat dibangun satu 
asumsi bahwa ketika mahasiswa mendapatkan bimbingan dan atau arahan yang benar terkait dengan penerapan metode triangulasi untuk uji validitas data sebagaimana dimaksud, sangatlah mungkin pelbagai kesalahan yang dilakukan oleh mahasiswa dalam penelitian dan penulisan skripsi tersebut akan dapat dihindarkan. Kemungkinan tafsir yang lain atas fenomena tersebut adalah, bisa jadi dosen (baik sebagai pengampu mata kuliah metodologi penelitian maupun sebagai pembimbing skripsi) kurang memahami persoalan tersebut, sehingga pelbagai praktik dan tindak kesalahan dalam penerapan teknik triangulasi oleh mahasiswa tidak disadari sebagai sebuah kesalahan, sehingga terusmenerus mendapatkan pembiaran karena dianggap sebagai realitas kebenaran.

Pemahaman hasil penafsiran tersebut berpotensi membawa “persoalan”, karena secara tidak langsung mengandung kritik yang tidak mengenakkan. Oleh karena itu, penulis mencoba melihat dalam konteks tarikan diskursif yang lebih mendasar dan bersifat meminimalisir dimensi perseorangan. Dalam hal ini, kemungkinan melihat persoalan tersebut dalam perspektif karakter keilmuan atau disiplin seni yang selama ini ada dan diyakini keberadaannya, menjadi satu bahan tilikan yang kiranya lebih komprehensif dan bermakna.

Yang dimaksud tilikan dari perspektif karakter keilmuan seni dalam konteks ini adalah bahwa keilmuan seni cenderung mengafirmasi satu ideologi yang cenderung menerjemahkan kesadaran keilmuannya dalam "basis karya seni” yang kurang diimbangi dengan dimensi lainnya, di antaranya yang terkait dengan konteks ini adalah "basis pengkajian/penelitian”. Fenomena ini sudah menjadi pemandangan yang sangat lama dan sampai saat ini relatif belum mengalami perubahan yang sangat berarti. Fakta tersebut patut diduga memberikan andil dan sumbangan yang besar terkait dengan persoalan tersebut.

\section{E. KESIMPULAN}

Berdasarkan data-data berikut hasil pembahasannya sebagaimana yang telah disajikan, maka penelitian ini dapat ditarik kesimpulan sebagai berikut. Pertama, terdapat tiga pola kategori kesalahan implementasi atau penerapan teknik triangulasi untuk kepentingan uji validitas atau kesahihah data penelitian. Ketiga pola ketegorisasi sebagaimana dimaksud adalah 1) kesalahan pemahaman dan implementasi konsep triangulasi berbasis penghadiran seorang ahli/pakar (expert judgment); 2) kesalahan pemahaman dan implementasi konsep triangulasi yang berbasis ketidakmampuan membedakan jenis teknik triangulasi yang digunakan; dan 3) kesalahan pemahaman dan implementasi konsep triangulasi yang berbasis ketidakjelasan konsep teknik triangulasi yang digunakan.

Kedua, faktor penyebab terjadinya kesalahan implementasi triangulasi pada uji validitas data skripsi mahasiswa Jurusan Pendidikan Seni Rupa, FBS, UNY melibatkan faktor internal dan eksternal. Faktor internal terkait dengan keberadaan mahasiswa sebagai pelaku yang melakukan kegiatan penelitian, berupa skripsi, yang terjadi karena keterbatasan pengetahuan yang benar yang dimiliki oleh mahasiswa, terutama terkait dengan keilmuan metodologi penelitian.

Faktor eksternal terkait dengan persoalan ini bersifat tidak tunggal. Satu hal yang penting dalam faktor eksternal adalah keberadaan dosen, baik dalam konteks pengampu mata kuliah metodologi penelitian seni maupun sebagai pembimbing penulisan skripsi, yang membantu memberikan pelbagai saran dan arahan ketika mahasiswa mengerjakan proses pembuatan skripsi. 
Di luar hal tersebut, tilikan dari perspektif karakter keilmuan seni, yang dalam konteks ini cenderung mengafirmasi satu ideologi kesadaran keilmuannya dalam "basis karya seni” yang kurang diimbangi dengan dimensi lainnya, di antaranya yang terkait dengan konteks ini adalah "basis pengkajian/penelitian”, patut diduga memberikan andil dan sumbangan yang besar terkait dengan persoalan tersebut. 


\section{DAFTAR PUSTAKA}

Alasuutari, Pertti. 1999. "Cultural Studies as A Construct”, dalam European Journal of Cultural Studies, Vol. 2 (1). London: Sage Publications.

Bandem, I Made. 2005. "Kekhasan Penelitian Bidang Seni”, Makalah Disajikan dalam Forum Diskusi Penelitian dan Pengabdian kepada Masyarakat Bidang Seni, DP3M Ditjen Dikti Depdiknas 7-9 September 2005 di Denpasar-Bali.

Engel, Rafael J. \& Schutt, Russell K.. 2010. “Chapter 4: Sampling”, in Fundamentals of Social Work Research. London: Sage Publication.

Fakultas Bahasa dan Seni, Universitas Negeri Yogyakarta. 2011. Panduan Penulisan Tugas Akhir. Yogyakarta: Fakultas Bahasa dan Seni.

Gie, The Liang. 2000. Filsafat Ilmu. Yogyakarta: Pusat Belajar Ilmu Berguna.

Halliday,Terence \& Janowitz, C. Morris. 1992. Sociology and Its Publics: The Forms and Fates of Disciplinary Organization. Chicago, USA: University of Chicago Press.

Johnson, R.B. 1995. “Estimating an Evaluation Model Using Conjoint Measurement and Analysis”. Evaluation Review Journal, 19 (13), 313-338.

Lubis, Akhyar Yusuf. 2010.Pengantar Filsafat Ilmu. Depok: Koekoesan.

Martopo, Hari. 2007. "Paradigma Baru Penelitian Seni”, Jurnal Harmonia Vol. VII no2 /2007.

Mendelsohn, Everett\& Elkana, Y. (eds.). 1981. Sciences and Cultures: Anthropological and Historical Studies of the Sciences. Dordrecht, Holland: Springer Science \& Business Media.

Miles, Matthew B. dan Huberman, A. Michael. 1992. Analisis Data Kualitatif: Buku Sumber tentang Metode-metode Baru. Terjemahan Tjetjep Rohindi Rohidi. Jakarta: Indonesia University Press.

Moleong, Lexy J. 2005. Metodologi Penelitian Kualitatif. Edisi Revisi.Cetakan Keduapuluhsatu. Bandung: Remaja Rosdakarya.

Muhadjir, Noeng. 2000. Metodologi Penelitian Kualitatif. Edisi IV.Yogyakarta: Rake Sarasin.

Sutopo, H.B. 2006. Metodologi Penelitian Kualitatif. Surakarta: Penerbit Universitas Sebelas Maret.

U.S. Congress, Office of Technology Assesment. 1985. Information Technology and R\&D: Critical Trend and Issues. Washington DC: U.S. Congress. 